\title{
PRODUCTION OF ISO-INTENSITY MAP FOR THE ELAZIG EARTHQUAKE (JAN 24, 2020) USING CITIZEN COLLECTED GEODATA
}

\author{
I. Yalcin ${ }^{1,2}$, S. Kocaman ${ }^{2}$, C. Gokceoglu ${ }^{3, *}$ \\ ${ }^{1}$ Bursa Uludag University, Gemlik Asim Kocabiyik Vocational College, 16600 Gemlik, Turkey - ilyasyalcin@uludag.edu.tr \\ ${ }^{2}$ Dept. of Geomatics Engineering, Hacettepe University, 06800 Beytepe Ankara, Turkey - sultankocaman@ hacettepe.edu.tr \\ 3* Dept. of Geological Engineering, Hacettepe University, 06800 Beytepe Ankara, Turkey - cgokce@ hacettepe.edu.tr
}

Commission V, WG V/3

KEY WORDS: Citizen Science, Earthquake, Disaster Management, Iso-Intensity Maps, Spatial Analysis

\begin{abstract}
:
Earthquake, depending on its intensity and location of epicentre, is one of the destructive hazards. Disaster mitigation after a severe earthquake are important to minimize its detrimental effects. Nowadays, several scientific disciplines, such as biodiversity, ecology, geosciences, natural hazards etc., utilize the Citizen Science (CitSci) approaches for various purposes, since the relevant attributes can easily be provided by non-experts with mobile devices. With the CitSci method, disaster related information can be identified and provided rapidly by locals during or after a disaster. Timely, in-situ data after an earthquake can also be collected with CitSci approaches via mobile devices, which can be even more important for all countries. In addition, scientific studies on earthquakes can be enriched and accelerated by using the information provided by volunteers. By collecting reliable data with the CitSci method, the disaster mitigation efforts can be improved, and losses may be decreased. This study aims at developing a CitSci pilot project by using the data collected by volunteers (citizens) to reduce the need for field work in creating earthquake isointensity maps and produce them promptly. The present study was based on the 6.8 Mw Elazig earthquake occurred at 20:55 UTC on January $24^{\text {th }}, 2020$. Through the mobile application "I felt the quake", the observations of citizens regarding the earthquake were collected. The intensities were revised from the Modified Mercalli Intensity Scale. With the help of data, an iso-intensity map was created and compared to the map produced by The Disaster and Emergency Management Presidency (AFAD), Turkey.
\end{abstract}

\section{INTRODUCTION}

The world is in a state of change, like a living organism, with all beings on it. Natural hazards going on throughout history have been seen as the results of these changes. Among natural hazards, earthquakes are the ones with the most destructive effects. Earthquakes cause both losses of life and substantial financial losses upon living beings (Swiss RE Group, 2019; Munich RE 2017). Mobile sensor technologies can be used to reduce the harmful effects of earthquakes and to improve the quality of risk management efforts after disasters.

As of January 2020, it has been reported that there are 4.5 billion Internet users and 3.8 billion social media users in the world (We Are Social, 2020). In addition, satellites that provide the Internet to the Earth orbit are sent with the Starlink (2020) Project to make the Internet usage even more widespread. In the light of these technological developments, it can be said that mobile device technology and the Internet usage rates will increase day by day. Scientific research can be contributed by using the Internet, mobile devices and social media data.

Citizen Science (CitSci) can be defined as the type of science that focuses on contributing to scientific studies by people who are not experts in research (Cohn, 2008). Within the scope of CitSci approach, many studies have been conducted on the management of natural disasters. A mobile application called
LaMA has been developed by Kocaman and Gokceoglu (2019) to help record landslides while Can et al. (2019) have ensured the control of data from users by revising LaMA application with its convolutional neural network (CNN) architecture. Kong et al. (2016) have developed a mobile application that has previously identified the earthquake and alerted its users. Liang et al. (2017) have worked towards increasing the awareness of the people about earthquakes and reducing the impact of the earthquake in Taiwan. Yalcin et al. (2020) have produced iso-intensity map employing the intensity values they have collected from users for the $(\mathrm{Mw}=5.8)$ earthquake occurred in Istanbul, Turkey. Gokceoglu et al. (2020a and b) have published technical reports on detailed review of Elazig (Sivrice) earthquake occurred on January, $24^{\text {th }}, 2020$. Eravci et al. (2013) produced iso-intensity map for Mugla (Ula) province from the data collected from users with eAFAD application. Hicks et al. (2019) analyzed over a hundred CitSci projects and collected these studies on a website. There are also studies in which data collected from the user through different platforms such as mobile application, web, are presented with a webbased GIS approach (e.g. Yalcin, 2018; Yalcin and Kocaman, 2018).

In Turkey, the use of such approaches are also extremely needed. Anatolian Plate is surrounded by North Anatolian Fault Zone, Eastern Anatolian Fault Zone, and Aegean horstgraben system and all these are seismically active. During the last two decades, several large earthquakes such as 1999

\footnotetext{
* Corresponding author
} 
Gölcük (Mw=7.5), 1999 Düzce (Mw=7.2), 2003 Bingöl $(\mathrm{Mw}=6.4), 2011$ Van $(\mathrm{Mw}=7.1), 2020$ Manisa (Akhisar) $(\mathrm{Mw}=5.4), 2020$ Elazig (Sivrice) $(\mathrm{Mw}=6.8)$, occurred. Following the main shocks, many aftershocks occurred. The earthquake intensity maps generated after an earthquake is crucial to analyze the disaster affected areas and very important for disaster mitigation efforts. Accurate production of such maps take a long time and requires fieldwork. In addition, the earthquake intensity felt by people is affected by ground conditions and the construction quality. Therefore, CitSci provide new opportunities for rapid production of earthquake intensity maps.

The aim of this study is to perform a CitSci pilot project by using the data obtained from volunteers (citizens) to reduce the need for field studies in creating earthquake iso-intensity maps and produce them quickly. The study performed here was based on the Elazig Earthquake ( $\mathrm{Mw}=6.8$ ) occurred on January 24th, 2020, at 20:55 UTC. Through the mobile app "I felt the quake" developed by Yalcin et al. (2020), the observations of citizens regarding the earthquake were collected. The intensities used in "I felt the quake" were revised from the Modified Mercalli Intensity Scale (MM). With the help of data, an iso-intensity map was created and compared to the map produced by The Disaster and Emergency Management Presidency (AFAD), Turkey.

\section{STUDY AREA}

Located in eastern Anatolian region in Turkey, Elazig province is surrounded by Tunceli in the north, Malatya in the west, Diyarbakir in the south and Bingol in the east. Elazig which is on the eastern Anatolian Fault Zone, has high earthquake activity. Over the past hundred years, 299 earthquakes with magnitudes $(\mathrm{Mw})$ of more than 4.0 have occurred in the region (AFAD, 2020). The last earthquake with a magnitude of Mw 6.8 has been stated in the report of AFAD, which occurred on the Sivrice-Pötürge segment of the Eastern Anatolian Fault Zone and the length of the segment is about 50-55 km (AFAD, 2020).

The iso-intensity map of the Elazig (Sivrice) earthquake was produced in this study with location-based user intensity values. In order to increase the number of user data and the accuracy of the map, user data from the surrounding provinces were utilized. For this reason, the study area was defined between $35,430^{\circ} \mathrm{E}-43,721^{\circ} \mathrm{E}$ longitudes, 36,157 $\mathrm{N}$ $40,933^{\circ} \mathrm{N}$ latitudes, including Elazig Province.

\section{METHODOLOGY}

\subsection{System Design and Implementation}

Compatible with Android 4.0.3 (Ice Cream Sandwich) and advanced versions, "I felt the quake" mobile application collects name, surname, sensible intensity scale value, date, time and location (coordinate values) data from users. The application is currently available on Google Play Store website and runs actively (Sarsintiyı Hissettim, 2019). PostgreSQL with PostGIS extension was chosen as database management system (DBMS) because it serves as an open source medium for storing the collected data and enabling fast spatial queries (PostgreSQL, 2020). The data fields of the app and their types in the spatial DBMS are provided in Table 1 (Yalcin et al., 2020).

\begin{tabular}{|l|l|}
\hline Column & Data type \\
\hline Id & Integer \\
Name & Character \\
Surname & Character \\
Intensity & Character \\
Latitude & Double precision \\
Longitude & Double precision \\
Date & Character \\
Time & Character \\
Transaction date and time & Timestamp \\
\hline
\end{tabular}

Table 1. The data fields of the developed mobile app and their storage types in the spatial DBMS (Yalcin et al., 2020).

Name and surname information are optionally provided by the user. There are date and time fields in the database to provide data entry from the user after the earthquake. The interface of the application and the map on which the user can choose the geographical location where he/she felt the earthquake are shown in Figure 1 (Yalcin et al., 2020). The selection of location data on the map in the application was provided by the PlacePicker API (Application Programming Interface) developed by Google (PlacePicker, 2020).

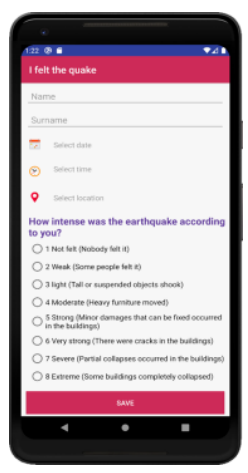

(a)

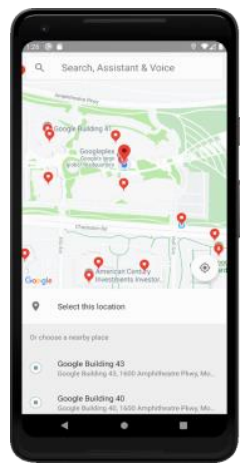

(b)
Figure 1. (a) Interface of the 'I felt the quake' application; (b) A screenshot from the 'Select location' interface (Yalcin et al., 2020).

The Modified Mercalli (MM) scale consisting of 12 different values developed in 1931 is a standardized scale used in the production of Earthquake iso-intensity maps (Wood and Neumann, 1931). The MM scale is actively used in web applications prepared by the United States Geological Survey (USGS) in accordance with the CitSci approach (USGS, 2020). The intensity values shown in the application interface in Figure 1(a) are rearranged based on the MM values commonly used today and these values are given in Table 2 (Yalcin et al., 2020). In total, 8 intensity values were obtained by subtracting $1,2,11$ and 12 values from the scale in the MM values; since it is almost impossible for the user to feel the weakest values (i.e. 1-2) and to send data from the strongest values (i.e. 1112). The purpose of reducing the MM values is to enable the user to easily mark the value that he/she felt. In this way, the provided scales are easily understandable by the users. 


\begin{tabular}{|c|c|c|}
\hline $\begin{array}{l}\text { Scale Value } \\
\text { in the } \\
\text { Mobile App }\end{array}$ & $\begin{array}{l}\text { Description of the } \\
\text { Intensity Scale in the } \\
\text { Developed App }\end{array}$ & $\begin{array}{l}\text { Corresponding } \\
\text { Modified } \\
\text { Mercalli } \\
\text { Intensity Scale }\end{array}$ \\
\hline 1 Not felt & Nobody felt it & 3 \\
\hline 2 Weak & Some people felt it & 4 \\
\hline 3 Light & $\begin{array}{l}\text { Tall or suspended } \\
\text { objects shook }\end{array}$ & 5 \\
\hline 4 Moderate & Heavy furniture moved & 6 \\
\hline 5 Strong & $\begin{array}{l}\text { Minor damages that can } \\
\text { be fixed occurred in the } \\
\text { buildings }\end{array}$ & 7 \\
\hline $\begin{array}{l}6 \text { Very } \\
\text { Strong }\end{array}$ & $\begin{array}{l}\text { There were cracks in the } \\
\text { buildings }\end{array}$ & 8 \\
\hline 7 Severe & $\begin{array}{l}\text { Partial collapses } \\
\text { occurred in the buildings }\end{array}$ & 9 \\
\hline 8 Extreme & $\begin{array}{l}\text { Some buildings } \\
\text { completely collapsed }\end{array}$ & 10 \\
\hline
\end{tabular}

Table 2. The relationship between MM Intensity Scale and values used in the app developed by Yalcin et al., (2020).

In the system architecture of the application running on the Android-based platform, as shown in Figure 2, name-surname (optional), date, time, location, and felt earthquake intensity value are entered and the save button is clicked by the user. These data provided by Amazon.com Inc., Seattle, U.S.A. are sent to Amazon Web Services (AWS) Ubuntu 16.04.6 LTS virtual machine. The web server transmits the data received from the user to the PostgreSQL positional database with the PostGIS extension. The data saved in the database returns to the user as a toast message.

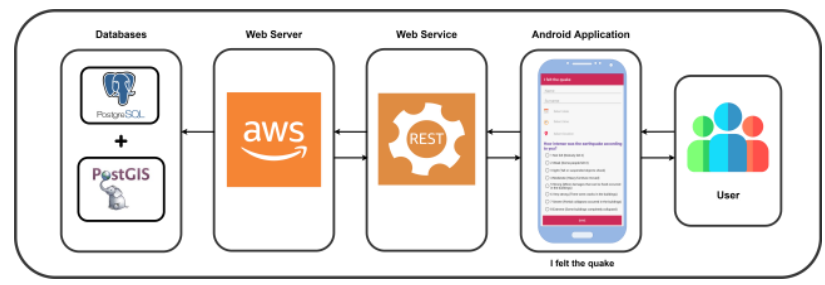

Figure 2. System architecture design of the application (Yalcin et al., 2020).

\subsection{Geostatical Analysis for Iso-intensity Map Production}

Defined also as a sub-discipline of statistics that is used effectively in determining spatial changes based on mathematical and statistical bases, Geostatistical analysis is used in many fields such as the determination of groundwater quality (Singh and Verma, 2019), resource and reserve estimation (Gandhi and Sarkar, 2016), production of earthquake iso-intensity maps (Yalcin et al., 2020). Kriging interpolation method, known as positional interpolation method in geostatistical approaches, includes many types such as ordinary kriging, simple kriging, universal kriging and cokriging. The kriging interpolation method applied by considering the semi-variance values of the distance between the point pairs, allows to calculate the values of the unknown points in the area statistically by using sample data in a field.
The semi-variance consisting of nugget, range and sill components is used as an expression of dissimilarity between point pairs (Oyana and Margai, 2015). The semi-variance value focuses on the distance between these points instead of the spatial coordinates of the sample points. The kriging methods estimate the value from known points to unknown points and calculate weight in relation to semi variance (O'sullivan and Unwin, 2014).

In this study, location-based earthquake intensity values collected from the users were calculated by ordinary kriging method to produce possible location-based earthquake intensity values within the whole study area. In Ordinary kriging method, local mean is calculated in the interpolation area while in simple kriging method, local mean is taken as a constant value. This creates the need to have prior knowledge about the field of study (Goovaerts, 1997).

\section{RESULTS AND DISCUSSION}

In this study, 161 data entries were retrospectively obtained in one and half month after January 24th, 2020 for $(\mathrm{Mw}=6.8)$ Elazig (Sivrice) earthquake. Whether the data collected by nonexpert users in CitSci studies is correct or not is of high significance. In order to prevent incorrect data provided by non-expert, users in the earthquake region were given training on the use and purpose of the mobile application. To make it sure that the collected data came from the real person, the name-surname information in the data was employed. As a result of filtering in this context, 121 records from the trained users were accepted as sample data.

In the study, the iso-intensity map in the January 2020 report prepared about the Elazig (Sivrice) earthquake by AFAD shown in Figure 3 (AFAD, 2020) was compared with the isointensity map created by ordinary kriging technique based on 121 sample data collected from the trained users. Elazig (Sivrice) earthquake maximum intensity value is presented as 9 in MM scale on AFAD map consisting of a legend with 12 MM intensity values. This value represents "7-Severe" among the revised values shown in Table 2 in the study. In Figure 4, the AFAD map, which is georeferenced according to The European Petroleum Survey Group (EPSG) 4326 projection system, and the sample data in EPSG 4326 projection system collected from users are shown together. It is seen that the intensity data provided by the user is higher than the isointensity map limits produced by AFAD. These data are also included in the study.

In the study, "4-Moderate" value provides the compatibility between the Iso-intensity map by AFAD and map formed according to the user data while there are not any values corresponding to the "1-Not Felt" value and the "8-Extreme" value in the field. There are also differences among other values. Because earthquake intensity value may vary in relation to variables such as age, height, and strength of the building. The compatibility between user intensity value and AFAD map is shown in Table 3. 


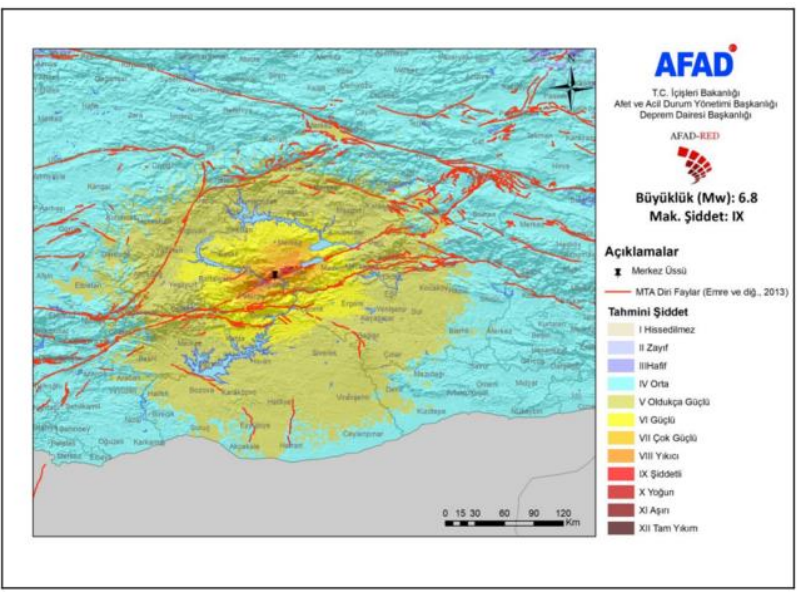

Figure 3. AFAD Earthquake Iso-intensity Map produced after the Elazig (Sivrice) Earthquake (Mw=6.8) (AFAD, 2020)

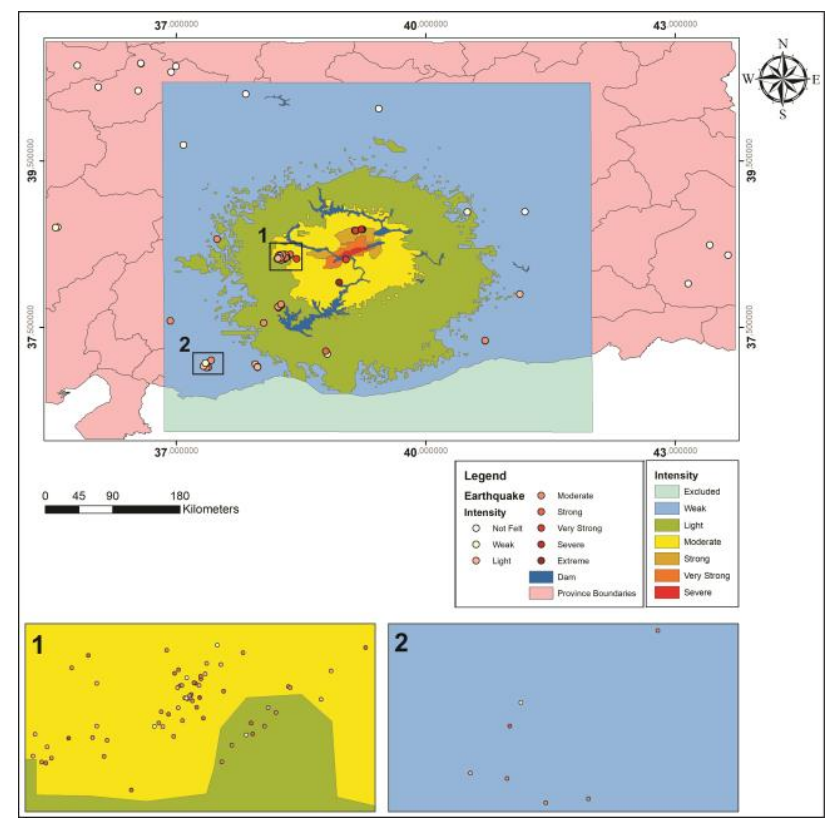

Figure 4. Data points collected in the study and AFAD Isointensity map; additionally zoomed views for two sub-parts.

\begin{tabular}{|l|c|c|c|}
\hline $\begin{array}{c}\text { App Scale } \\
\text { Number }\end{array}$ & $\begin{array}{c}\text { Overall } \\
\text { Frequency }\end{array}$ & $\begin{array}{c}\text { Frequency } \\
\text { within } \\
\text { AFAD map } \\
\text { boundaries }\end{array}$ & $\begin{array}{c}\text { Number of } \\
\text { data } \\
\text { matching } \\
\text { AFAD map }\end{array}$ \\
\hline 1 (Not felt) & 13 & 3 & No data \\
\hline 2 (Weak) & 11 & 9 & 3 \\
\hline 3 (Light) & 24 & 24 & 2 \\
\hline 4 (Moderate) & 38 & 38 & 21 \\
\hline 5 (Strong) & 20 & 20 & 0 \\
\hline 6 (Very strong) & 13 & 12 & 1 \\
\hline 7 (Severe) & 1 & 1 & 0 \\
\hline 8 (Extreme) & 1 & 1 & No data \\
\hline
\end{tabular}

Table 3. The number of intensity values obtained on the AFAD map and the data collected in the study.
The results of ordinary kriging interpolation with 121 sample data provided by the user are shown in Figure 5, and the semivariogram of the interpolation is shown in Figure 6. According to the result of the interpolation, the lowest and the highest intensity values were calculated as 0,99 and 6,5 respectively. The interpolation map was produced based on the semi variogram shown in Figure 6. If a comparison between the isointensity map produced in the present study (Figure 6) and the field observations provided by Gokceoglu et al. (2020b), there is a good accordance between the iso-intensity values and the earthquake damages.

The horizontal axis of the semi-variogram shows the distance between the point pairs while the vertical axis shows the half variance value. Since the distance (in degrees) between the point pairs decreases in the variance values after the 2,49 range value, the semi-variogram takes values around the peak variance value. As the distance between the point pairs decreases, the similarity between points will increase. As shown in Table 3, the presence of extreme value affects the variance between the points in an area where intensity values are expected to be lower than the earthquake intensity.

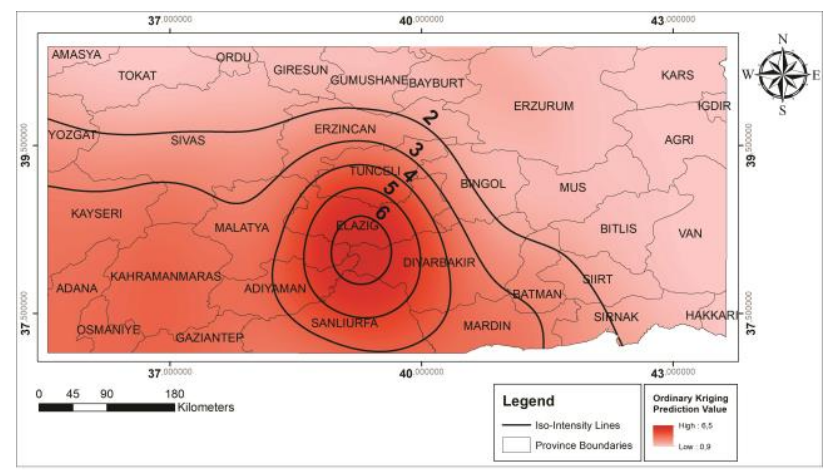

Figure 5. Interpolation map produced from the data collected in the study using the ordinary kriging method.

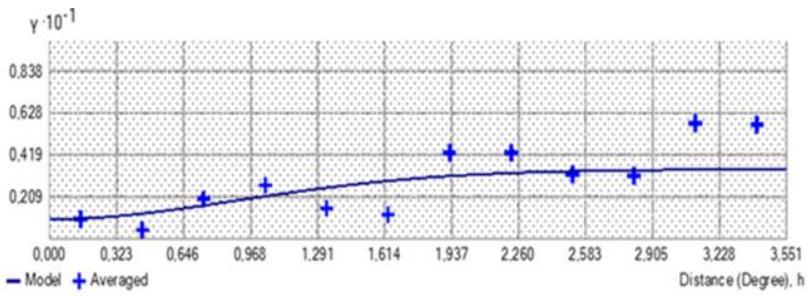

Figure 6. Variogram produced from the data collected in the study.

The comparison of two iso-intensity maps illustrates that the accuracy of the iso-intensity maps produced after the earthquake can be questioned. This indicates that there are some challenges in iso-intensity map production. The main problem is the uncertainty of the exact location of the epicentre that triggered the earthquake. Besides, it is not possible for the earthquake to affect the entire settlement area at the same intensity. Because some buildings in the area are new and durable, some buildings may be old and worn out. In addition, the height of the buildings will directly affect the intensity values and the local ground conditions will also affect the intensity. With this study, CitSci approach was used to reduce the uncertainties sourced from these problems. Unlike sensors providing information on a single field, CitSci can obtain 
accurate information on many fields such as earthquake intensity from each local dwelling. Thus, scientific studies can be contributed by collecting data on different fields from a volunteer.

The most important factor in CitSci studies is the accuracy of the collected data. As seen in this study, it is the data coming from trained users that facilitates the application of the interpolation method. Grounding CitSci studies on data from trained users may provide more accurate and more reliable results. Therefore, users should often be given a preliminary training on projects. In this study, obtaining sample data in isointensity map production in large numbers and evenly distributed in the field can make the results more accurate. For this reason, more citizens should be encouraged to take part in CitSci studies and it should be ensured that citizens see themselves as part of scientific projects.

\section{CONCLUSION}

In this study, which is about the production of iso-intensity map of $(\mathrm{Mw}=6.8)$ Elazig (Sivrice) earthquake that occurred at 20:55 UTC on January $24^{\text {th }}, 2020$, it was made use of the CitSci approach. A total of 121 location-based intensity values were obtained from trained users in the surrounding provinces of the Elazig earthquake. In the light of these data, iso-intensity map was produced employing ordinary kriging spatial interpolation method. The methodology used in this study was also used for the September 26th, 2019 Istanbul earthquake $(\mathrm{Mw}=5.8)$ (Yalcin et al., 2020).

As seen in the results of both studies, there are some minor problems on iso-intensity maps produced after the earthquake. The difference between the map produced from the user data and the AFAD map is due to the intensity values used in the iso-intensity map production. The differences in intensity values vary depending on the quality, height, age of the building and the local ground conditions on which it is located. In the study, it has been shown that CitSci method can be used reliably to overcome these problems.

In order to obtain correct results in CitSci projects, citizens' data must be accurate and reliable. To make this possible, technologies such as machine learning (ML), CNN, and artificial neural network (ANN) can be used or users can be trained on the project prior to the CitSci project or both can be preferred. In this study, it was preferred to give pre-project training to users. In addition, existence of correct and large number of data distributed in the region on iso-intensity map production will increase the accuracy of the map. The use of understandable and participant friendly questionnaire and mobile application in CitSci projects to collect data can help get better results. In this context, the revision on the scale of 12 MM eliminated the uncertainty of the users in selecting the earthquake intensity value. In addition, the mobile application's being clear, simple and understandable provided an easy use to the citizens.

It is expected that the number and the diversity of CitSci projects will increase and help to improve the scientific studies by training the society around these projects. CitSci studies, which will diminish field studies in the production of earthquake iso-intensity maps, will reduce the cost of scientific studies and can help to obtain the results faster. The present study was one of the first and did not focus on the speed of the production, but in fact it is possible to obtain the results in a few hours. In addition, the integration of CitSci method with Internet and mobile device technology will enable societies that cannot allocate high budget for scientific research subjects to produce projects scientifically.

\section{ACKNOWLEDGEMENTS}

The authors thank sincerely to the volunteers who provided the data about the earthquake intensity.

\section{REFERENCES}

AFAD, 2020. Sivrice (Elazig) Mw 6.8 Depremine İlişkin Ön Değerlendirme Raporu. Technical Report T.C. İçişleri Bakanlığı Afet ve Acil Durum Yönetim Başkanlığı, January. https://deprem.afad.gov.tr/downloadDocument?id=1825 (last accessed on 30 April 2020)

Can, R., Kocaman, S., Gokceoglu, C., 2019. A convolutional neural network architecture for auto-detection of landslide photographs to assess citizen science and volunteered geographic information data quality. ISPRS International Journal of Geo-Information, 8, 300.

Cohn, J.P., 2008. Citizen Science: Can Volunteers Do Real Research? BioScience 58, 192-197.

Eravci, M.B., Yanik, K., Yenilmez, G., Yalcin, D., ve Fahjan, Y., 2013. Ak1llı Telefonlar Aracilığ ile Deprem Sonras1 Şiddet Tahmini, 2. Türkiye Deprem Mühendisliği ve Sismoloji Konferansi, Antakya, Turkey, 25-27 September.

Gandhi, S.M., Sarkar, B.C., 2016. Geostatistical Resource/Reserve Estimation, Essentials of Mineral Exploration and Evaluation. Elsevier, pp. 289-308.

Gokceoglu, C., Yurur, M.T., Kocaman, S., Nefeslioglu, A.H., Durmaz, M., Tavus, B., Karakas, G., Buyukdemircioglu, M., Atasoy, K., Yoruk, I., Can, R., Yalcin, I., 2020a. Radar İnterferometrisi ve Stereo Hava Fotogrametrisi ile Elazig Sivrice Depreminin (24 OCAK 2020, M W =6.8) İncelenmesi. Technical report Hacettepe University Faculty of Engineering. Available online: http://fs.hacettepe.edu.tr/ muhfak/dosyalar /Duyurular/HU-GEO-JEO_Elazig_Sivrice_raporu.pdf. DOI: 10.13140/RG.2.2.19673.88167

Gökçeoğlu, C., Şahmaran, M., Unutmaz, B., Aldemir, A., Koçkar, M.K., Sandıkkaya, A., İçen, A., 2020b. 24 OCAK 2020 -ELAZIĞ SIVRİCE DEPREMİ (M W $=6.8$ ) ÖN İNCELEME RAPORU Şubat 2020. Technical report Hacettepe Üniversitesi Mühendislik Fakültesi İnşaat Mühendisliği Bölümü. Available from: https://www.researchgate.net/publication/339164891. DOI: $10.13140 /$ RG.2.2.30561.45921

Goovaerts, P., 1997. Geostatistics for natural resources evaluation. Oxford University Press on Demand, New York, USA. p.416. ISBN 0-9-511538-4.

Hicks, A., Barclay, J., Chilvers, J., Armijos, M.T., Oven, K., Simmons, P., Haklay, M., 2019. Global Mapping of Citizen 
Science Projects for Disaster Risk Reduction. Frontiers in Earth Science, 7.

Kocaman, S., Gokceoglu, C., 2019. A CitSci app for landslide data collection. Landslides 16, 611-615.

Kong, Q., Allen, R.M., Schreier, L., Kwon, Y.-W., 2016. MyShake: A smartphone seismic network for earthquake early warning and beyond. Science advances 2, e1501055.

Liang, W.-T., Lee, J.-C., Chen, K.H., Hsiao, N.-C., 2017. Citizen earthquake science in Taiwan: from science to hazard mitigation. Journal of Disaster Research 12, 1174-1181.

Munich RE, 2017. https://www.munichre.com/topicsonline/en/climate-change-and-natural-disasters/naturaldisasters/overview-natural-catastrophe-2016.html (last accessed on 26.04.2020)

O'sullivan, D., Unwin, D., 2014. Geographic information analysis. John Wiley \& Sons. p. 406. ISBN 9780470288573.

Oyana, T.J., Margai, F., 2015. Spatial analysis: statistics, visualization, and computational methods. CRC Press. p. 305. ISBN 978-1498707633.

PlacePicker, 2020.

https://developers.google.com/android/reference/com/google/an $\mathrm{droid} / \mathrm{gms} /$ location/places/ui/PlacePicker (last accessed on 28.04.2020)

PostgreSQL, 2020. https://www.postgresql.org/ (last accessed on 28.04.2020)

Sarsintıyı Hissettim, 2019.

https://play.google.com/store/apps/details?id=com.ilyas.asus.po stgresqlsample2\&gl=TR (last accessed on 28.04.2020)

Singh, P., Verma, P., 2019. A Comparative Study of Spatial Interpolation Technique (IDW and Kriging) for Determining Groundwater Quality, GIS and Geostatistical Techniques for Groundwater Science. Elsevier, pp. 43-56. doi.org/10.1016/B978-0-12-815413-7.00005-5.

Starlink, 2020. https://www.starlink.com/ (last accessed on 27.04.2020)

Swiss RE Group, 2019. https://www.swissre.com/media/newsreleases/nr-20191219-global-catastrophes-estimate.html (last accessed on 26.04.2020)

USGS, 2020. The Modified Mercalli Intensity Scale, 2020. https://www.usgs.gov/natural-hazards/earthquakehazards/science/modified-mercalli-intensity-scale?qtscience_center_objects $=0 \# q t-s c i e n c e$ _center_objects accessed on 28.04.2020)

We Are Social, 2020. https://wearesocial.com/digital-2020 (last accessed on 27.04.2020)

Wood, H.O., Neumann, F., 1931. Modified Mercalli intensity scale of 1931. Bulletin of the Seismological Society of America, 21, 277-283.
Yalcin, I., 2018. Açık Kaynaklı Web Tabanlı Coğrafi Bilgi Sistemi Geliştirilmesi. Master's Thesis Hacettepe, University, Ankara, Turkey. p. 112.

Yalcin, I., Kocaman, S., Gokceoglu, C., 2020. A CitSci Approach for Rapid Earthquake Intensity Mapping: A Case Study from Istanbul (Turkey). ISPRS International Journal of Geo-Information, 9, 266. doi.org/10.3390/ijgi9040266

Yalcin, I., Kocaman, S., 2018. Açık Kaynaklı Web Tabanlı Coğrafi Bilgi Sistemi Geliştirilmesi. VII. Uzaktan Algılama ve CBS Sempozyumu Uzal-CBS 2018, Eskisehir, Turkey, 18-21 September. 